\title{
Direct serum and tissue assay for EGFR mutation in non-small cell lung cancer by high-resolution melting analysis
}

\author{
CHENGJIN HU $^{1}$, XIAOLEI LIU ${ }^{1}$, YINGJIAN CHEN ${ }^{1}$, XIAOMING SUN ${ }^{1}$, \\ YANWEN GONG ${ }^{1}$, MING GENG $^{2}$ and LIQUAN BI ${ }^{2}$ \\ Departments of ${ }^{1}$ Laboratory Medicine and ${ }^{2}$ Pathology, General Hospital of \\ Jinan Military Command, Jinan, Shandong 250031, P.R. China
}

Received June 6, 2012; Accepted August 2, 2012

DOI: $10.3892 /$ or.2012.1987

\begin{abstract}
Biological therapy with epidermal growth factor receptor tyrosine kinase inhibitors (EGFR-TKIs) have noted promising outcomes for patients with non-small cell lung carcinoma (NSCLC), especially those with mutated EGFR. Tissue EGFR gene mutation testing can predict the benefit of taking a first-line EGFR-TKI, thus, allowing the physician to prescribe the most suitable therapy. Unfortunately, most lung cancer patients, especially NSCLC patients present with advanced disease that is surgically unresectable. The goal of this study was to develop high-resolution melting (HRM) assays to detect EGFR mutations in exons 18 to 21, compare their sensitivity and concordance to direct sequencing, and evaluate the feasibility and reliability of serum as a tissue alternate for routine EGFR mutation screening. EGFR mutations of 126 Formalin-Fixed Paraffin-Embedded (FFPE), 47 fresh frozen tissues and from 47 matched pre-operation serum specimens of NSCLC patients were screened by the HRM assays. EGFR mutations by HRM were confirmed through sequencing. We found 78 EGFR mutations in 70 FFPE tissues, 25 EGFR mutations in 24 fresh frozen tissues, with a mutation rate of 55.56\% (70/126) and 51.06\% (24/47), respectively. Most mutations were correctly identified by sequencing. EGFR mutations were detected in 22 serum samples from 24 tissue EGFR mutation-positive patients. The concordance rate between serum and tissue in EGFR mutation screening was $91.67 \%$. We conclude that the HRM assay can provide convincing and valuable results both for serum and tissues samples, thus, it is suitable for routine serum EGFR mutation screening for NSCLC patients, especially those surgically unresectable.
\end{abstract}

Correspondence to: Professor Chengjin Hu, Department of Laboratory Medicine, General Hospital of Jinan Military Command, 25 Shifan Road, Jinan, Shandong 250031, P.R. China

E-mail: med-lab@yahoo.cn

Key words: epidermal growth factor receptor, mutation, non-small cell lung carcinoma, high-resolution melting

\section{Introduction}

Lung cancer is the leading cause of cancer-related death in worldwide, and accounts for one third of all deaths (1). Current treatment of lung cancer is still based on traditional surgery. Unfortunately, most lung cancer patients, especially non-small cell lung cancer (NSCLC) patients present advanced disease that is surgically unresectable. It is current practice to treat these patients with a combination of chemotherapy and external beam irradiation. But treatment outcomes for NSCLC remain unsatisfactory, with low long-term survival rates $(<15 \%)$. Emerging TARGETED therapy with epidermal growth factor receptor tyrosine kinase inhibitors (EGFR-TKIs) are currently being evaluated in NSCLC.

EGFR is a receptor tyrosine kinase (TK) which is widely distributed in mammalian epithelial cells, glial cells, fibroblasts, keratinocytes and other cell surface. EGFR family includes four structurally-related tyrosine kinase receptors: EGFR (ErbB-1), HER2/c-neu (ErbB-2), Her3 (ErbB-4). These receptors are related to $70 \%$ of cancer (2). Abnormal activation of EGFR can promote tumor cell proliferation, differentiation, migration. EGFR has been found to be overexpressed in a variety of human malignancies $(2,3)$. Activation of EGFR results in the initiation of a diverse range of cellular signaling pathways, including cell proliferation and protection of the cell from apoptosis (4). In 2004, Lynch et al (5) and Paez et al (6) proposed the EGFR gene mutations in lung cancer can be predicted, which is considered a milestone for NSCLC individualized targeted molecular therapies. These mutations are located in EGFR exons 18-21 (7) and 90\% of the sensitizing mutations are in-frame deletions in exon19, and the point mutation L858R in exon 21 (8). These mutations cluster around the ATP binding pocket of the tyrosine kinase domain of EGFR, leading to ligand-independent activation of the receptor and prolonged activation time compared to wild-type EGFR. Although exon 20 mutations were less, it is associated with resistance to anti-EGFR therapies (9-11).

The treatment of NSCLC using EGFR-TKIs, such as gefitinib and erlotinib was confirmed, showing promising outcomes for some patients with NSCLC, especially those with mutated EGFR $(5,6,12)$. EGFR mutations increase sensitivity to TK inhibitors, most likely through induction of critical structural modifications of the ATP-binding site in the 
Table I. HRM primer sequences.

\begin{tabular}{lllcc}
\hline Exon & \multicolumn{1}{c}{ Primer } & $\mathrm{T}\left({ }^{\circ} \mathrm{C}\right)$ & $\mathrm{G} / \mathrm{C}(\%)$ & Amplicon size $(\mathrm{bp})$ \\
\hline \multirow{2}{*}{18} & F: CTGAGGTGACCCTTGTCTCTGTGTTC & 66.63 & 53.85 & 183 \\
& R: AGGCCTGTGCCAGGGACCTTA & 67.36 & 61.90 & 204 \\
\multirow{2}{*}{20} & F: GCATGTGGCACCATCTCACAA & 64.42 & 52.38 & \multirow{2}{*}{228} \\
& R: CCTGAGGTTCAGAGCCATGGA & 64.88 & 57.14 & \\
& F: CATTCATGCGTCTTCACCTG & 60.30 & 50.00 & 236 \\
& R: TCTTTGTGTTCCCGGACATAG & 60.00 & 47.60 & 50.00 \\
\end{tabular}

$\mathrm{F}$, forward; $\mathrm{R}$, reverse.

TK domain (13). EGFR mutation testing may be prognostically important to guide identify potential responders (or nonresponders) to therapy. Therefore, a rapid, sensitive and reliable method for EGFR mutations testing is required.

The classic method for detecting EGFR mutations is direct sequencing. However, sequencing for routine testing is impeded by relatively high cost, requirement of sophisticated equipment and technical expertise, which are often only available in specialized molecular pathology laboratories (14). HRM is a recently developed technique that shows great potential for somatic mutations (15), but rarely uses serum samples. In 1989, studies have shown that the DNA in the plasma of cancer patients had tumor characteristics (16). In 1994, Sorenson et al and Vasioukhin et al detected the same gene mutation in tumor and plasma, this discovery confirmed that a part of free DNA from tumor existed in plasma $(17,18)$. However, the clinical development of EGFR mutation detection was impeded by the low sensitivity of conventional methods, because the tumor DNA levels in peripheral blood is extremely low. In this study, we aimed to establish a sensitive and reliable HRM method for routine EGFR mutation screening using serum, which will benefit many NSCLC patients, especially those surgically unresectable.

\section{Materials and methods}

Samples. A total of 126 FFPE specimens (71 adenocarcinomas, 53 squamous cell carcinomas, one large cell carcinoma, and one adenosquamous carcinoma) between December 2008 and September 2010, 47 fresh frozen surgically resected tumor tissues (28 adenocarcinomas, 19 squamous cell carcinomas) between October 2010 and June 2011 were obtained from tumor tissue bank of Department of Pathology at Jinan General Hospital of PLA. All tissues were finally diagnosed as NSCLC by Pathology. We also successfully collected 47 matched preoperation serum specimens for the 47 NSCLC patients between October 2010 and June 2011.

DNA extraction. The paraffin rolls were cut from each block (5 sections of 5- $\mu \mathrm{m}$ thickness) for DNA extraction. About $300 \mathrm{mg}$ fresh frozen tissue was used for DNA extraction. QIAamp DNA FFPE tissue kit (Qiagen) and QIAamp
DNA mini kit (Qiagen) was used to extract FFPE and fresh frozen tissue DNA, respectively. DNA was extracted from $200 \mu 1$ serum using QIAamp DNA blood mini kit (Qiagen). All DNA solutions were quantitated with the Lambda Bio Spectrophotometer system (PerkinElmer Company, USA), adjusted to the same concentration of $30 \mathrm{ng} / \mu \mathrm{l}$, and then stored at $-20^{\circ} \mathrm{C}$ until use.

Design of HRM primers. Primers specific for EGFR exons 18 to 21 were designed using Primer Designer Software (primer premier 5.0). Primers that flanked the exons as closely as possible were chosen. All primers were analyzed for specificity and to ensure similar melting temperatures using Primer-BLAST software. The sequences of primers for the EGFR exon 18 to 21 were listed in Table I. All amplicons were less than $250 \mathrm{bp}$ and covered the most common EGFR mutations.

Real-time PCR and HRM assay. Real-time PCR and HRM assays were performed with LightCycler ${ }^{\circledR} 480$ Real-time system (Roche Diagnostics, Switzerland). Each $20 \mu 1$ reaction system contained $\sim 30 \mathrm{ng}$ DNA, 1X LightCycler HRM Master reaction mix (Roche Diagnostics), $2.5 \mathrm{mM} \mathrm{MgCl}_{2}$, and $4 \mu \mathrm{M}$ forward and reverse primer (HPLC purified). The same PCR program was used for all amplicons: $95^{\circ} \mathrm{C}$ for $10 \mathrm{~min} ; 50$ cycles of $95^{\circ} \mathrm{C}$ for $10 \mathrm{sec}, 60^{\circ} \mathrm{C}$ for $15 \mathrm{sec}$. After amplification, a post amplification melting curve program was initiated by heating to $95^{\circ} \mathrm{C}$ for $1 \mathrm{~min}$, cooling to $60^{\circ} \mathrm{C}$ for $1 \mathrm{~min}$, and increasing the temperature to $95^{\circ} \mathrm{C}$ while continuously measuring fluorescence at 25 acquisitions per degree. Each PCR run contained a negative (no template) control. Data were acquired and analyzed using LC480 Gene Scanning software V1.5 (Roche Diagnostics). All curves were analyzed following normalization, temperature shifting, and the inspection of difference plots.

Specificity and sensitivity of HRM assays. All amplified products were sent to sequence, and then were analyzed for specificity to ensure the homology of EGFR gene using BLAST (19). Sequence analysis was performed with Chromas 2.31 software. To test the sensitivity, we mixed the genomic DNA of the EGFR-mutated sample with wild-type DNA sample in dilutions of 50, 25, 12.5, 10, 5 and 2.5\%, and then HRM were performed, PCR products were also sequenced. 

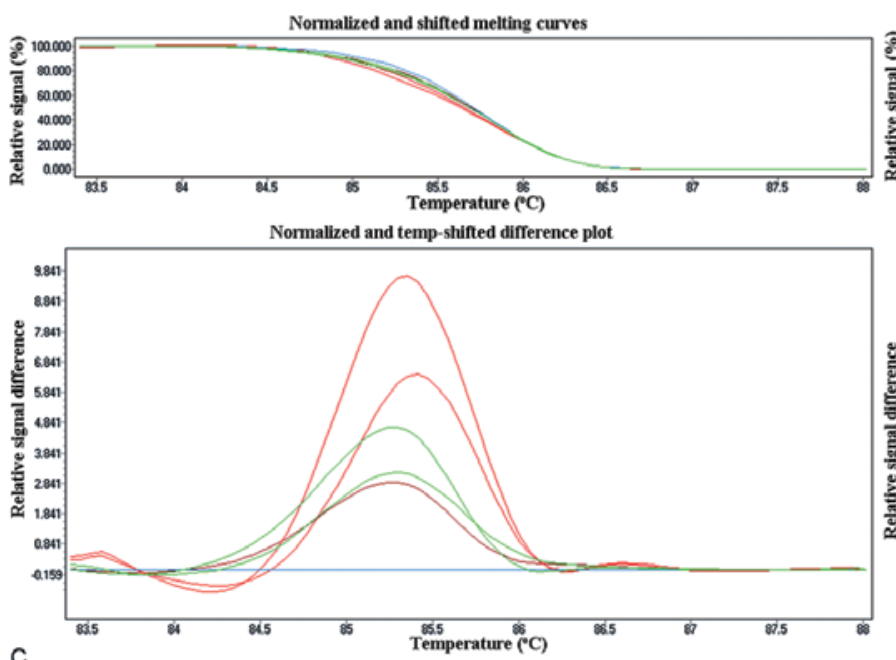

c

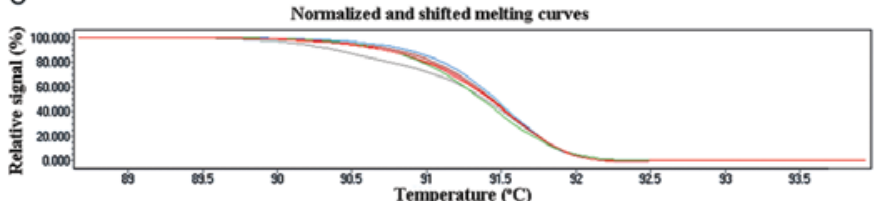

Normalized and temp-shifted difference plot

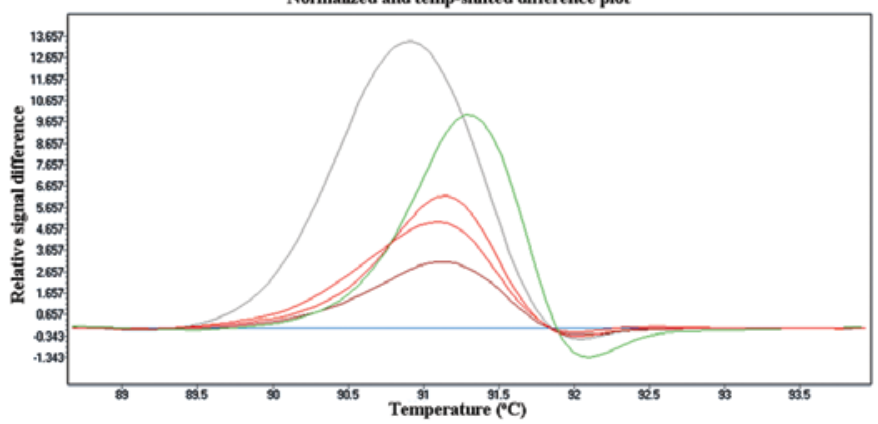

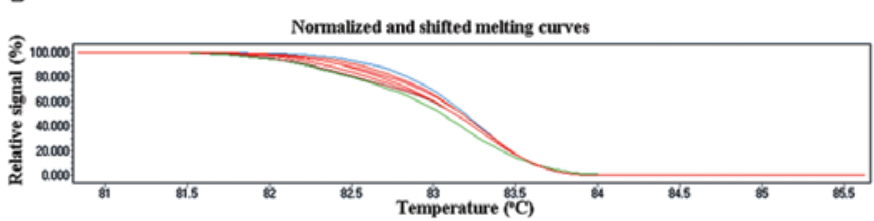

Normalized and temp-shifted difference plot

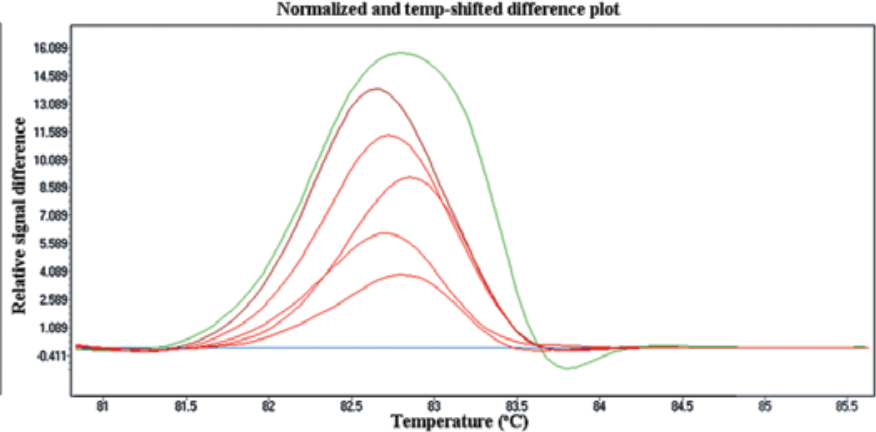

D

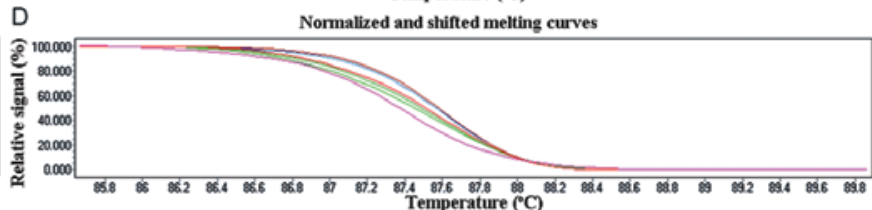

Normalized and temp-shifted difference plot

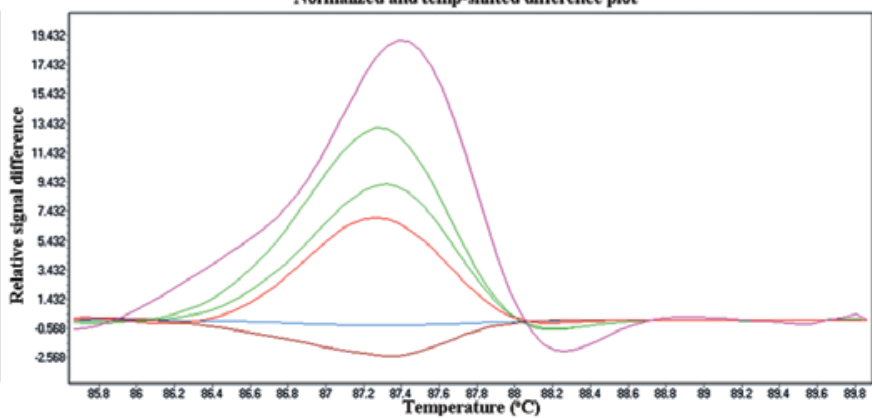

Figure 1. Sensitivity of the EGFR HRM assay. Using HRM, the mutation was readily detectable at $5 \%$ mutation frequency in exon 18 (A), exon 20 (C) and exon 21 (D). Adjusted melting curves (top) and differential plots (bottom) showing the presence of 50,25, 12.5, 10,5 and 0\% mutant. The $2.5 \%$ dilution was not distinct from the normal DNA. (B) The sensitivity of exon 19, it can detect $2.5 \%$ dilution. Adjusted melting curves (top) and differential plots (bottom) showing the presence of $50,25,12.5,10,5,2.5$ and $0 \%$ mutant.

EGFR mutation rate screening by HRM. All 126 FFPE specimens, 47 fresh frozen tissue samples and 47 serum specimens were tested by HRM for the detection of mutations in EGFR exons 18-21. Samples were amplified in 96-well plates.

Statistical analysis. SPSS statistical software (version 17) was used for statistical analysis. Difference of EGFR mutation between FFPE and fresh frozen tissue samples were analyzed with Fisher's exact test. The correlation between the presence of EGFR mutation status and the clinicopathological categorical characteristics was assessed by Logistic Regression. A twotailed p-value of $<0.05$ was statistically significant.

\section{Results}

Specificity and sensitivity of EGFR HRM assay. Amplicons sequences were verified using BLAST to search the NCBI GenBank. The sensitivity was evaluated by detection of serial dilutions of EGFR-mutated sample. HRM assays for EGFR exons 18, 19, 20, and 21 mutations were detected in dilution of $5,2.5,5$, and 5\%, respectively (Fig. 1). While EGFR mutations were detected by direct sequencing in dilutions of 50 and 25 , 12.5 , but not $<10 \%$.

EGFR mutation status in FFPE and fresh frozen tissues of $N S C L C$. Difference plots and sequence traces of representative mutations for each amplicon are depicted in Fig. 2, with Table II showing the results obtained. EGFR mutations (78) were detected in 70 NSCLC FFPE samples by HRM, with a total mutation rate of $55.56 \%$ (70/126). Among all the mutations, there were 5 in exon 18 (3.97\%), 23 in exon 19 (18.25\%), 27 in exon $20(21.42 \%)$, and 23 in exon $21(18.25 \%)$. 74 EGFR mutation identified by HRM were confirmed by direct sequencing. There were 5 in exon 18 (G719S), 22 in exon 19 (2236-225Del), 25 in exon 20 (3 insertion mutation, 22 Q787Q nonsense mutation), and 22 in exon 21 (20 L858R, 2 L861Q). In addition, 8 patients were found to have double EGFR mutations, 4 in exon 19 and exon 20, 3 in exon 20 and exon 21, one in exon 18 and exon 21. We found 25 EGFR mutations in 24 fresh frozen NSCLC tissues; the total mutation rate was $51.06 \%$ (24/47). There was one in exon 18 (2.13\%, G719S), 8 in exon $19(17.02 \%, 2236-2250$ Del), 9 in exon 20 (19.15\%, Q787Q nonsense mutation), and 7 

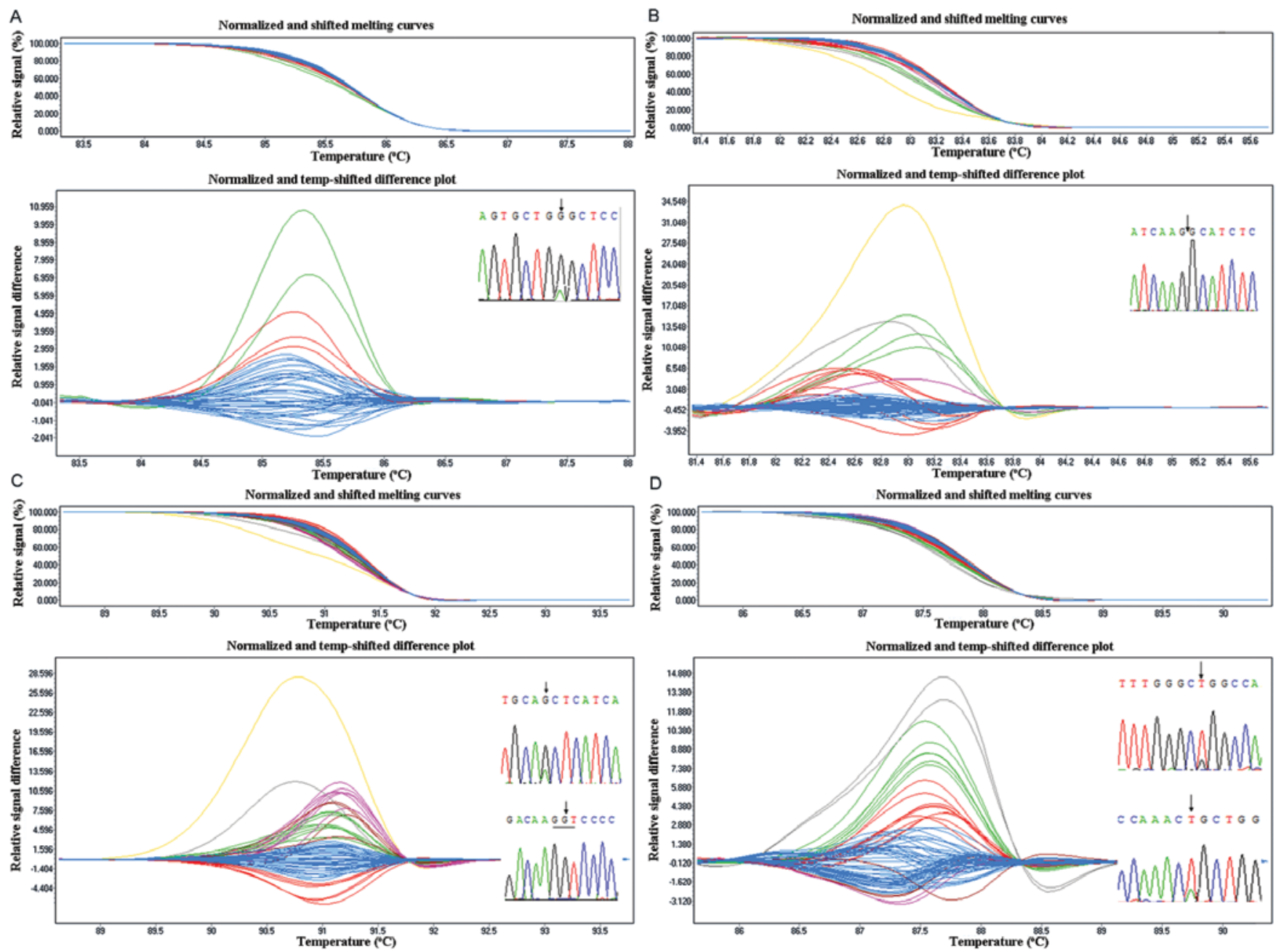

Figure 2. HRM assays and sequence traces for EGFR. The amplification plot of EGFR exons 18-21 shows aberrant shifting of melting curves from the wildtype (WT, blue line). Difference plot showing two different melting profiles, wild-type samples in blue (WT), mutation in other colors. (A) Exon 18 mutations, genotype is E-18 2155G $>\mathrm{A}(\mathrm{G} 719 \mathrm{~S})$. (B) Exon 19 mutations, genotype is 2236-2250 del (GAATTAAGAGAAGCA). (C) Exon 20 mutations, genotypes are 2310-2311 insGGT and 2359G>A (Q787Q). (D) Exon 21 mutations, genotypes are 2573T>G (L858R) and 2582T>A (L861Q).

in exon 21 (14.89\%, L858R), one in exon 19 and exon 20. There was no difference in the mutation status between FFPE and fresh frozen tissues $(\mathrm{P}>0.05)$.

In addition, there was an obvious Tm shift between the insertion mutation (2310-2311 ins GGT) and Q787Q nonsense mutation in exon 20 , so we could easily differentiated the two mutation types by setting positive mutation standard. However, the two exon 21 mutation types could not be identified through HRM.

Serum EGFR mutations testing. EGFR mutations were detected in 22 serum samples from 24 fresh frozen tissue EGFR mutations positive NSCLC patients (Table III). The serum positive rate was $100 \%(13 / 13)$ for those tissue EGFR mutations positive patients in stages II-IV, $81.8 \%(9 / 11)$ for stage I. No false negative was found in stage II-IV patients, while there was $18.2 \%$ false negatives for stage I patients. Therefore, the sensitivity of serum EGFR screening by HRM assay was $91.67 \%$, specificity $100 \%$.

Relationship between EGFR mutations and clinicopathological factors. The correlation between clinicopathological characteristics of the patients and EGFR mutations is summarized in Table IV. EGFR mutations were detected more frequently in never-smokers than smokers $(81.03 \%$ versus $33.82 \%$; $\mathrm{P}<0.01)$, females than males $(90.48 \%$ versus $38.10 \%$; $\mathrm{P}<0.05)$, adenocarcinoma histology compared to squamous cell carcinoma $(76.06 \%$ versus $28.30 \%$; $\mathrm{P}<0.01)$. EGFR mutation status did not show any significant association with clinical staging $(\mathrm{P}=0.197)$.

\section{Discussion}

Personalized medicine for cancer has raised new hope of cancer treatment, and become widely used in clinical settings over the last decade. Based on specific genetic information of various cancers, it had become possible to determine the genetic type of cancer, select the appropriate treatment, then enhance drug efficacy and reduce toxicity. However, the effectiveness of these new introduced molecular targeted drugs was closely dependent on the presence of specific genetic mutations in the tumor context (20-22). Gene mutation testing is the premise to using molecular-targeting drugs. EGFR gene mutations have recently been identified as a predictor for 
Table II. EGFR mutations detected by HRM and sequencing.

\begin{tabular}{|c|c|c|c|c|c|}
\hline \multirow[b]{2}{*}{ Mutation in } & \multicolumn{2}{|c|}{$\operatorname{HRM}(\%)$} & \multicolumn{2}{|c|}{ Gene sequencing } & \multirow[b]{2}{*}{ Genotype } \\
\hline & FFPE & Frozen & FFPE & Frozen & \\
\hline Exon 18 & $5(3.97)$ & $1(2.13)$ & 5 & 1 & G719S \\
\hline Exon 19 & $23(18.25)$ & $8(17.02)$ & 22 & 8 & 2236-2250Del \\
\hline Exon 20 & $27(21.42)$ & $9(19.15)$ & $\begin{array}{r}22 \\
3\end{array}$ & $\begin{array}{l}8 \\
0\end{array}$ & $\begin{array}{l}\text { Q787Q } \\
\text { 2310-2311insGGT }\end{array}$ \\
\hline Exon 21 & $23(18.25)$ & $7(14.89)$ & $\begin{array}{r}20 \\
2\end{array}$ & $\begin{array}{l}6 \\
0\end{array}$ & $\begin{array}{l}\text { L858R } \\
\text { L861Q }\end{array}$ \\
\hline Exon $18+$ exon 21 & $1(1.28)$ & 0 & 1 & 0 & G719S and L858R \\
\hline Exon $19+$ exon 20 & $4(5.13)$ & $1(4.17)$ & 4 & 1 & $\begin{array}{l}\text { 2236-2250Del } \\
\text { and Q787Q }\end{array}$ \\
\hline Exon $20+$ exon 21 & $3(3.85)$ & 0 & 3 & 0 & Q787Q and L858R \\
\hline Total mutations & 78 & 25 & 74 & 23 & \\
\hline Cases & $70(55.56)$ & $24(51.06)$ & 66 & 22 & \\
\hline
\end{tabular}

first-line EGFR-TKIs sensitivity (23). It was shown that $70 \%$ of EGFR mutation-positive NSCLC patients were effective to EGFR-TKIs, while only $10 \%$ of EGFR mutation- negative NSCLC patients (24). In addition, the responses of patients with different EGFR mutation types to EGFR-TKIs treatment were also different (25-27). Thus, it is of great importance to detect EGFR mutation status and type for NSCLC patients, which can effectively predict the benefit of taking an EGFR-TKI, and allow the physician to prescribe the most suitable therapy.

There are several methods for EGFR mutation testing, such as PCR-SSCP, gene chips and gene sequencing, with the gene sequencing being the current gold standard (28). HRM is a technique recently developed on the basis of real-time PCR amplification, which shows great potential for somatic mutations. A double stranded DNA binding dye is utilized in melting analysis in order to characterize primer-related non-specific amplification (or primer dimer) for detection of a specific target (29). Compared with traditional real-time PCR, HRM which adopt saturated dye have higher resolution, even single-base change can make the melting temperature of PCR products different (30). All the processes of PCR amplification followed by HRM take place in the same tube during a real-time run in $<2 \mathrm{~h}$ (31). Therefore, HRM is the method of choice for rapid EGFR mutation screening.

In our study, we confirmed that both FFPE and fresh frozen tissue can be used for the HRM method. Mutation rates of FFPE and fresh frozen tissue are compatible; fresh frozen tissues showed no better than FFPE as others have reported (29). In addition, we found that HRM method could be used to differentiate 2310-2311insGGT and Q787Q mutation in exon 20 if known positive mutations control were properly set. However, HRM failed to identify the two mutation types in exon 21; sequencing had to be done to discriminate them.

Owing to the fact that tissue samples cannot be obtained from most of the lung cancer patients, the use of EGFR mutation screening in tissue samples is limited in practice. Plasma or serum which has free DNA from tumor provides as good alternative. However, the tumor DNA levels in peripheral blood are extremely low, which needs a more sensitive method for detection. The HRM assays described herein successfully identified EGFR mutations not only in tissue specimens but also in serum samples from NSCLC patients. The concordance rate between serum and fresh frozen tissues was better than in a previous report (32). The HRM assays acted perfectly in serum from NSCLC patients in stage II-IV, and no false negative was found. In addition, for NSCLC patients in stage I, most mutations can also be detected despite the $18.2 \%$ false negative rate. The sensitivity and specificity for serum EGFR screening by HRM was 91.67 and $100 \%$, respectively. Therefore, HRM assays using serum samples for EGFR mutation screening can act as a good alternative for tissue screening, provide convincing and valuable results for the physician, and benefit surgically unresectable NSCLC patients.

The reported EGFR mutation rate in NSCLC patients differs and varies from 5 to $48.3 \%(30,32,33)$. It was shown that EGFR mutations were found in $~ 10 \%$ of cases of NSCLC in North America and 30-50\% of NSCLC patients of East Asian descent (7). The frequency of the activating mutations is higher in Asian populations (34). In our research, the total EGFR mutation rate was $55.56 \%$, which is the highest so far. This result may suggest the EGFR mutation rate of people in eastern China must be higher than other regions. In addition, many reports suggest major activating EGFR mutations are primarily in exons 19 and 21, with the inframe deletion in exon 19 and L858R accounting for $90 \%$ of reported mutations, additional mutations do occur in exons 18 and 20 that account for $8 \%$ of mutants (35). However, we found in this region of china, EGFR mutation occurs in exon 20 more often, especially Q787Q, and then in exons 19 and 21. Therefore, we should not only detect EGFR mutation in exons 19 and 21, but must attach great importance in EGFR exon 20 mutation detection in this region. We recommend that EGFR mutations in exons 18-21 
Table III. Summary of data of 24 serum samples.

\begin{tabular}{|c|c|c|c|c|c|c|}
\hline Case & Gender & Age & Histologic type & Staging & Smoking status & Mutation \\
\hline 1 & M & 55 & $\mathrm{Ad}$ & IIIA & $\mathrm{C}$ & Exon 20 \\
\hline 2 & M & 58 & $\mathrm{Ad}$ & IIA & $\mathrm{N}$ & Exon 20 \\
\hline 3 & F & 54 & SCC & IV & $\mathrm{N}$ & Exon 19 \\
\hline 4 & $\mathrm{M}$ & 65 & $\mathrm{SCC}$ & IA & $\mathrm{C}$ & Exon 20 \\
\hline 5 & M & 57 & SCC & IB & $\mathrm{C}$ & Exon 20 \\
\hline 6 & M & 70 & $\mathrm{Ad}$ & IB & $\mathrm{C}$ & Exon 21 \\
\hline 7 & $\mathrm{~F}$ & 75 & $\mathrm{Ad}$ & IIA & $\mathrm{N}$ & Exon 21 \\
\hline 8 & M & 59 & Ad & IIB & $\mathrm{N}$ & Exon 18 \\
\hline 9 & M & 64 & SCC & IB & $\mathrm{C}$ & Exon 20 \\
\hline 10 & $\mathrm{~F}$ & 51 & $\mathrm{Ad}$ & IIIA & $\mathrm{N}$ & Exon 19 \\
\hline 11 & F & 51 & Ad & IIA & $\mathrm{N}$ & Exon 21 \\
\hline 12 & M & 74 & SCC & IIA & $\mathrm{C}$ & Exon 19 \\
\hline 13 & $\mathrm{~F}$ & 62 & Ad & IIIA & $\mathrm{N}$ & Exon 20 \\
\hline 14 & M & 76 & SCC & IIA & $\mathrm{C}$ & Exon 19 \\
\hline 15 & $\mathrm{~F}$ & 59 & Ad & IIIA & $\mathrm{N}$ & Exon 19 \\
\hline 16 & $\mathrm{~F}$ & 70 & $\mathrm{Ad}$ & IA & $\mathrm{N}$ & Exon 21 \\
\hline 17 & F & 63 & Ad & IA & $\mathrm{N}$ & Exon 21 \\
\hline 18 & M & 53 & SCC & IB & $\mathrm{C}$ & Exon 20 \\
\hline 19 & $\mathrm{~F}$ & 63 & SCC & IB & $\mathrm{N}$ & Exon 19 \\
\hline 20 & M & 62 & SCC & IIA & $\mathrm{C}$ & Exon 20 \\
\hline 21 & M & 46 & SCC & IIA & $\mathrm{C}$ & Exon 19 \\
\hline 22 & $\mathrm{~F}$ & 68 & $\mathrm{Ad}$ & IA & $\mathrm{N}$ & Exon 19 \\
\hline 23 & F & 76 & $\mathrm{Ad}$ & IA & $\mathrm{N}$ & Not detected \\
\hline 24 & F & 74 & $\mathrm{Ad}$ & IB & $\mathrm{C}$ & Not detected \\
\hline
\end{tabular}

F, female; M, male; Ad, adenocarcinoma; SCC, squamous cell carcinoma; C, current; N, never.

Table IV. Relationship between EGFR mutations and clinicopathological factors.

\begin{tabular}{lcccr}
\hline & \multicolumn{2}{c}{ EGFR mutation } & & \\
\cline { 2 - 3 } & No. patient & P-value & EGFR wild-type & Total \\
\hline Total no. patient & 70 & - & 56 & 126 \\
Gender & & & 52 & 84 \\
Male & 32 & & 4 & 42 \\
Female & 38 & 0.028 & & 58 \\
Smoking history & & & 11 & 68 \\
Never & 47 & 0.004 & 45 & 71 \\
Former/current & 23 & & 7 & 53 \\
Histological diagnosis & & & 38 & 1 \\
Adenocarcinoma & 54 & 0.003 & 1 & 1 \\
Squamous cell carcinoma & 15 & & - & 89 \\
Large cell carcinoma & - & & \\
Adenosquamous carcinoma & 1 & & 40 & 35 \\
Staging & & 0.197 & 14 & \\
I-II & 49 & & & \\
III-IV & 21 & & & \\
\hline
\end{tabular}


should be detected before prescribing an EGFR-TKI for NSCLC patients from eastern China.

There have been debates on the relationships between EGFR mutation state and clinical characteristics $(14,33,36)$. Our data showed EGFR mutations were more frequently observed in never-smokers, females, and those with adenocarcinoma histology, and there was no correlation between different clinical stages. Our results are comparable to those of Sriram et al (14) and Takano et al (33).

In summary, we have confirmed the feasibility of HRM for screening EGFR mutations in serum. Serum EGFR gene mutation screening by HRM assays are fast, relatively cheap, and robust, and can benefit surgically unresectable NSCLC patients; provide rapid scientific reference to the physician, and guide them to prescribe the most suitable therapy.

\section{References}

1. Sasaki H, Endo K, Konishi A, et al: EGFR mutation status in Japanese lung cancer patients: genotyping analysis using LightCycler. Clin Cancer Res 11: 2924-2929, 2005.

2. Nicholson RI, Gee JM and Harper ME: EGFR and cancer prognosis. Eur J Cancer 37 (Suppl 4): S9-S15, 2001.

3. Ohsaki Y, Tanno S, Fujita Y, et al: Epidermal growth factor receptor expression correlates with poor prognosis in non-small cell lung cancer patients with p53 overexpression. Oncol Rep 7: 603-607, 2000

4. Scaltriti M and Baselga J: The epidermal growth factor receptor pathway: a model for targeted therapy. Clin Cancer Res 12: 5268-5272, 2006.

5. Lynch TJ, Bell DW, Sordella R, et al: Activating mutations in the epidermal growth factor receptor underlying responsiveness of non-small-cell lung cancer to gefitinib. N Engl J Med 350: 2129-2139, 2004.

6. Paez JG, Janne PA, Lee JC, et al: EGFR mutations in lung cancer: correlation with clinical response to gefitinib therapy. Science 304: 1497-1500, 2004.

7. Shigematsu H, Lin L, Takahashi T, et al: Clinical and biological features associated with epidermal growth factor receptor gene mutations in lung cancers. J Natl Cancer Inst 97: 339-346, 2005.

8. Borras E, Jurado I, Hernan I, et al: Clinical pharmacogenomic testing of KRAS, BRAF and EGFR mutations by high resolution melting analysis and ultra-deep pyrosequencing. BMC Cancer 11: 406-415, 2011.

9. Yasuda H, Kobayashi S and Costa DB: EGFR exon 20 insertion mutations in non-small-cell lung cancer: preclinical data and clinical implications. Lancet Oncol 13: e23-e31, 2011.

10. Murray S, Dahabreh IJ,Linardou H, Manoloukos M, Bafaloukos D and Kosmidis P: Somatic mutations of the tyrosine kinase domain of epidermal growth factor receptor and tyrosine kinase inhibitor response to TKIs in non-small cell lung cancer: an analytical database. J Thorac Oncol 3: 832-839, 2008.

11. Linardou H, Dahabreh IJ,Bafaloukos D, Kosmidis P and Murray S: Somatic EGFR mutations and efficacy of tyrosine kinase inhibitors in NSCLC. Nat Rev Clin Oncol 6: 352-366, 2009.

12. Han SW, Kim YT, Hwang PG, et al: Predictive and prognostic impact of epidermal growth factor receptor mutation in nonsmall-cell lung cancer patients treated with gefitinib. J Clin Oncol 23: 2493-2501, 2005.

13. Carey KD, Garton AJ, Romero MS, et al: Kinetic analysis of epidermal growth factor receptor somatic mutant proteins shows increased sensitivity to the epidermal growth factor receptor tyrosine kinase inhibitor, erlotinib. Cancer Res 66: 8163-8171, 2006.

14. Sriram KB, Tan ME, Savarimuthu SM, et al: Screening for activating EGFR mutations in surgically resected nonsmall cell lung cancer. Eur Respir J 10: 455-465, 2011.
15. Taylor CF: Mutation scanning using high-resolution melting. Biochem Soc Trans 37: 433-437, 2009.

16. Stroun M, Anker P, Maurice P, Lyautey J, Lederrey C and Beljanski M: Neoplastic characteristics of the DNA found in the plasma of cancer patients. Oncology 46: 318-322, 1989.

17. Sorenson GD, Pribish DM, Valone FH, Memoli VA, Bzik DJ and Yao SL: Soluble normal and mutated DNA sequences from single copy genes in human blood. Cancer Epidemiol Biomarkers Prev 3: 67-71, 1994.

18. Vasioukhin V, Anker P, Maurice P, Lyautey J, Lederrey C and Stroun M: Point mutations of the N-ras gene in the blood plasma DNA of patients with myelodysplastic syndrome or acute myelogenous leukaemia. Br J Haematol 86: 774-779, 1994.

19. NCBI/BLAST: http://blast.ncbi.nlm.nih.gov/Blast.cgi.

20. Horn L and Pao W: EML4-ALK: Honing in on a new target in non-small-cell lung cancer. J Clin Oncol 27: 4232-4235, 2009.

21. Choi YL, Soda M, Yamashita Y, et al: EML4-ALK mutations in lung cancer that confer resistance to ALK inhibitors. N Engl J Med 363: 1734-1739, 2010.

22. Pao W and Girard N: New driver mutations in non-small-cell lung cancer. Lancet Oncol 12: 175-180, 2011.

23. Sequist LV, Bell DW, Lynch TJ and Haber DA: Molecular predictors of response to epidermal growth factor receptor antagonists in non-small-cell lung cancer. J Clin Oncol 25: 587-595, 2007.

24. Uramoto $\mathrm{H}$ and Mitsudomi T: Which biomarker predicts benefit from EGFR-TKI treatment for patients with lung cancer? Br J Cancer 96: 857-863, 2007.

25. Jackman DM, Yeap BY, Sequist LV, et al: Exon 19 deletion mutations of epidermal growth treated with gefitinib or erlotinib. Clin Cancer Res 12: 3908-3914, 2006.

26. Riely GJ, PaoW, Pham D, et al: Clinical course of patients with non-small cell lung cancer and epidermal growth factor receptor exon 19 and exon 21 mutations treated with gefitinib or erlotinib. Clin Cancer Res 12: 839-844, 2006.

27. Mitsudomi T, Kosaka T, Endoh H, et al: Mutations of the epidermal growth factor receptor gene predict prolonged survival after gefitinib treatment in patients with non-small cell lung cancer with postoperative recurrence. J Clin Oncol 23: 2513-2520, 2005.

28. Pao W and Ladanyi M: Epidermal growth factor receptor mutation testing in lung cancer: searching for the ideal method. Clin Cancer Res 13: 4954-4955, 2007.

29. Bosquet JG, Calcei J, Wei JS, et al: Detection of somatic mutations by high-resolution DNA melting (HRM) analysis in multiple cancers. PLoS One 6: e14522, 2011.

30. Nomoto K, Tsuta K, Takano T, et al: Detection of EGFR mutations in archived cytologic specimens of non-small cell lung cancer using high resolution melting analysis. Am J Clin Pathol 126: 608-615, 2006

31. Camila GC and Mauricio RL: The use of high-resolution melting analysis for genotyping Symbiodinium strains: a sensitive and fast approach. Mol Ecol Resour 11: 394-399, 2011.

32. Sriram KB, Tan ME, Savarimuthu SM, et al: Screening for activating EGFR mutations in surgically resected nonsmall cell lung cancer. Eur Respir J 38: 903-910, 2011.

33. Takano T, Ohe Y, Tsuta K, et al: Epidermal growth factor receptor mutation detection using high-resolution melting analysis predicts outcomes in patients with advanced non small cell lung cancer treated with gefitinib. Clin Cancer Res 18: 5385-5390, 2007.

34. Bell DW, Lynch TJ, Haserlat SM, et al: Epidermal growth factor receptor mutations and gene amplification in non-small-cell lung cancer: molecular analysis of the IDEAL/INTACT gefitinib trials. J Clin Oncol 23: 8081-8092, 2005.

35. Sharma SV, Bell DW, Settleman J and Haber DA: Epidermal growth factor receptor mutations in lung cancer. Nat Rev Cancer 7: 169-181, 2007.

36. Smith GD, Chadwick BE, Willmore-Payne C and Bentz JS: Detection of epidermal growth factor receptor gene mutations in cytology specimens from patients with non-small cell lung cancer utilising high-resolution melting amplicon analysis, J Clin Pathol 61: 487-493, 2008. 